\title{
Elements of Hard Landscape Design and New Approaches on Their
}

\section{Use}

\author{
Esra ŞENTÜRK*, T. Hakan ALTINÇEKİÇ
}

Istanbul University, Faculty of Forestry, Program of Landscape Architecture, Department of Landscape Planning and Design, Bahcekoy/Istanbul

*Corresponding author: esrasntrk28@gmail.com

Received Date: 07.11.2017

Accepted Date: 16.11.2018

\begin{abstract}
Aim of study: The objective of the research is classification of hard landscape design materials and reveal the new approaches in their usage.

Area of study: This study was conducted in different cities of Europe, Turkey and America.

Material and Methods: First stage of the study method consists of determination of the research subject and its areas. Subsequently literature research was carried out and studies conducted within our country and abroad were examined. After sufficient information was obtained, it was proceeded to field work. At this stage, hard landscape design elements were examined and photographed from different cities Europe, Turkey and America to determine the new approaches in current usage.

Main results: It is observed, in line with the evaluations made, that hard landscape designers can respond to contemporary approaches, new expectations and applications and are intertwined with other disciplines such as natural and social sciences as well as technical, visual, artistic and architectural, disciplines compared to the past.

Research highlights: It has been tried to bring new offers as regards the usage of hard landscape elements in landscape design work to be carried out in Turkey. Moreover, ecological use (selection of light colored materials, usage as to water saving and etc.) in addition to their functional and aesthetic usage possibilities have also been included.
\end{abstract}

Keywords: Elements of hard landscape design, horizontal elements, vertical elements, landscape design

\section{Sert Peyzaj Tasarım Elemanları ve Kullanımlarındaki Yeni}

\section{Yaklaşımlar}

$\ddot{\mathbf{O} z}$

Çalışmanın amacı: Sert peyzaj tasarım elemanlarının sınıflandırılması ve kullanımlarındaki yeni yaklaşımları ortaya koymaktır.

Çalışma alanı: Bu çalışma Avrupa, Türkiye ve Amerika'nın farklı şehirlerinde gerçekleştirilmiştir.

Materyal ve Yöntem: Çalışma yönteminin ilk aşamasını araştırma konusunun ve alanlarının belirlenmesi oluşturmaktadır. Ardından literatür araştırması yapılmış, konu ile ilgili yurt içinde ve dışında yapılan çalışmalar incelenmiştir. Yeterli bilgiler elde edildikten sonra arazi çalışmasına geçilmiştir. Güncel kullanımlarındaki yeni yaklaşımları belirlemek amacıyla Avrupa, Amerika ve Türkiye'den değişik kentlerde görsel saptamalar yapılmış ve sunulmaya çalışılmıştır.

Temel Sonuçlar: Yapılan değerlendirmelerde sert peyzaj tasarım elemanlarının çağdaş yaklaşımlara, yeni beklentilere ve uygulamalara cevap verebildiği, geçmişe oranla doğal ve sosyal bilimlerle, teknik, görsel, sanatsal ve mimari gibi diğer disiplinlerle iç içe olduğu görülmektedir.

Araştırma vurguları: Türkiye'de yapılacak peyzaj tasarım çalışmalarında, sert peyzaj elemanlarının kullanımına yeni öneriler getirilmeye çalışılmıştır. Ayrıca fonksiyonel ve estetik kullanım olanaklarına ek olarak ekolojik kullanımlarına da (açık renkli malzeme seçimi, su tasarrufuna yönelik kullanımları, vb.) yer verilmiştir.

Anahtar kelimeler: Sert peyzaj tasarım elemanları, yatay elemanlar, düşey elemanlar, peyzaj tasarımı

This article is based on a master's thesis submitted by Esra ŞENTÜRK to the Department of Landscape Planning and Design at İstanbul University Institute of Graduate Studies in Science and Engineering. Prof. Dr. T. Hakan ALTINÇEKİÇ served as thesis supervisor. 


\section{Introduction}

Humans have been primarily involved in activities related to earth subsequent to passing to sedentary life with a view to meet their fundamental requirements such as provision of shelter and food. Over time, humans have created gardens in line with cultural and sociological developments with the desire of enjoying the areas they live in and turned their involvement with earth into art (Akdoğan, 1974).

Landscape design elements have been classified as soft and hard landscape design elements and subsequently dimensions of these elements have reached urban scales from small scales such as house gardens while it is also observed in contrast that vertical garden systems are also utilized in our houses as in the form of terrariums or in other words miniature gardens. This situation comprising different subjects and scales indicates the versatility of landscape design elements. This study reveals the fact that hard landscape design elements have a significant place in terms of providing a positive contribution in terms of improving the visual quality of the environment, creation of more livable places and development of urban identity.

Classification of hard landscape design elements and examination of hard landscape design elements in terms of quality and usage have been made primarily in this study. Furthermore, new approaches in current use have also been photographed at their places of application and presented in addition to classic understanding of usage in landscape design. Ecological uses (selection of light colored materials, usage related to saving water and etc.) as well as functional and aesthetic usage possibilities have also been included.

New proposals as regards the utilization of hard landscape design elements in landscape design works to be carried out in Turkey have been tried to be brought forward as a consequence of the study.

Hard landscape, to put it simply, denotes bricks, flooring plates, wooden fences, metal railings, structures and all other non-living outdoor landscape elements (Blake, 2015).

Albeit their contribution to the visual quality of the environment as well as their significance in terms of maintenance and resistance in the long run, hard landscape design elements are mostly considered as a concept to be included later in the design process and are not given the importance they deserve. Significance of hard floor landscape within the urban context and urban furniture within the use of public should be highlighted with principles. These principles should be in compliance with the content in design plans, their functions should be fulfilled as required, their social usage should be supported and cleaning, maintenance and moving of these materials should be easy and their connection parts should be used. It should also be noted that material quality of hard landscape design elements is an important issue. Much as high quality products are obviously more expensive than standard products their being long-lasting as well as their low maintenance costs close the cited gap (Punter and Carmona, 2011).

While plants have a significant emphasis in landscape design works, hard landscape design elements also have an important effect. Hard landscape design elements provide entertainment and recreation thereby increasing open space possibilities. Hard landscape design elements also provide a focal point within the landscape and solve secrecy and security issues. A good planned hard landscape design ensures a more livable and easy maintainable landscape. A good selected and established hard landscape elements help to increase the value of the land (Sagers, 2005).

Several factors should be considered while selecting hard landscape materials. These factors include the following:

Fitness for content: Materials should contribute to the feature of local distinctiveness and must complete the appearance of the environment.

Fitness for purpose: Materials should be designed in a way to meet requirements.

Sustainability: Materials should be selected and built in a way to minimize need for maintenance in future. Repair and replacement requirements should be taken into account during selection and building.

Work quality: Work quality must be applied 
at the highest standards. Otherwise, high quality materials can be broken or worn out quickly.

General construction costs: Material costs and required expenditures must be taken into consideration.

Environmental effect: Production sources of materials and energy effects, their use and recycling are also issues which require attention. (Landscape SPD, 2011).

When we observe classification of hard landscape elements we see that there are various classifications. Some of them are listed below:

According to Başer (2002) the classification of hard landscape elements is made as flooring elements, accessory elements, water elements and rocks.

Hard landscape elements (artificial landscape design elements) are classified as base elements, limitation and containment elements, water elements and accessory elements (city furniture) according to Genç (2006).

According to Shakouri (2010) hard landscape elements (Structural Elements Used in Landscape) are classified as floor elements, vertical elements, cover elements and accessory elements.

According to Bird (2014) the classification of hard landscape elements is made as horizontal elements and vertical elements.

According to Yildizc1 (2001), city furniture is classified as follows in line with their functions:

1. Floor coverings (concrete, stone, wood, asphalt, brick and etc.),

2. Sitting units (benches, chairs, seating components group),

3. Lighting elements (way illuminators, field illuminators),

4. Signs and information plates (guides, place indicators, information communication panels),

5. Bollard sand (deterrents, bollards , pedestrian barriers, traffic barriers, etc.),

6. Water elements (ornamental ponds, fountains, pumps, ducts, fire taps and etc.),

7. Shelter items (bus-stops, shades, pergolas), 8. Sales units (kiosks, exhibition pavilions, buffets etc.),
9. Art objects (statues),

10. Other items (flag poles, trash cans, mail boxes, public toilets, flower beds, ticket vending machines, bicycle parking racks, park meters, vegetal items).

As is seen, because all the classifications made for hard landscape design elements cover completely urban furniture, it was considered based on the classification made by Bird (2014) that it would be more appropriate to classify the hard landscape design elements as horizontal elements and vertical elements which would also be compliant with all the works carried out in the recent years.

\section{Horizontal Elements}

Design studies in landscape architecture works begin with horizontal elements namely the floor elements which are considered to be the first and basic element of space.

\section{Vertical Elements}

Vertical elements include a building, a pot, a sculpture or an attractive tree. If there is nothing to be focused on, your eye wanders aimlessly and the "picture" becomes meaningless (Alexander, 2009). As such, vertical elements have more visuality than horizontal elements unarguably. Vertical elements have been classified as lighting units, signs and information plates, sitting units, bollards, water element, shelter items, sales units, artistic objects, playground elements and other elements.

\section{Qualifications and Usage of Hard Landscape Design Elements}

It will not be the right choice to use the same hard landscape design elements in a small scale landscape project and urban scale landscape project. Each material and design element must be suitable and fit for the feature of the place where the landscape project will be made.

Qualities and functions of hard landscape design elements are as follows:

-They create connections between the gardens, houses and buildings,

-They surround the space and give a meaning to the space and create privacy and comfort. They also provide safety

-They provide vehicle and pedestrian entry of 
circulation in some areas while they prevent vehicles and pedestrians,

-They create integrity with the environment they are placed in terms of aesthetic, appearance and function so that when they are designed they provide an aesthetic look instead of a disorganized look,

-They provide a versatile combination. For example: traffic plates, traffic lights, barriers and lighting elements can be combined with each other,

-Floor differences, ramps, audible traffic lamps and etc. provide support to disabled people,

-Furthermore, it should be noted that they need maintenance because they reflect the sun's rays and usually cause reflections. Moreover, there are some issues to be considered in the hard landscape design. They are as follows:

1) Usage of brick different forms in and contrasting textures as well as the use of creative floor works such as terrazzo, mosaics, contemporary art or handicrafts and etc.,

2) Fixation of large, flat flags, paving stones and stones used in vehicle roads,

3) Usage of metal railings or metal fences reduce the risk of attack compared to walls and wooden fences,

4) Provision of access to everywhere (provision of level changes by virtue of steps, ramps and handrails, use of flooring material suitable for wheels and considering the widths and etc.),

5) Choosing the place of hard landscape design elements (for example: banks must provide options according to change of air conditions like in sunny, shaded or enclosed areas),

6) Fixed, strong, durable and non-slip surfaces must be used to ensure safety,

7) Use of lighting which highlights hard and soft landscape details but avoidance of creating deep shadows,

8) Provision of drainage to reduce the flow at the surface level (Punter and Carmona, 2011).

\section{Material and Methods}

The subject of the research is classification of hard landscape design elements and revealing new approaches in their usage. Studies conducted as regards the subject were examined firstly with a view to make this classification. Subsequently, visual detections were made in different cities in Europe and America to determine the new approaches in current usage. The examples we examined in the detections comprise photographs taken from the places we examined. The examples in cities within our country and abroad specified in terms of functional, aesthetic and ecological use of hard landscape design elements were utilized as material. First stage of the study method consists of determination of the research subject and its areas. Subsequently literature research was carried out and studies conducted within our country and abroad were examined. After sufficient information was obtained, it was proceeded to field work. At this stage, hard landscape design elements were examined and photographed from cities abroad such as Vienna (Austria), Prague (Czech Republic), Budapest (Hungary), Bratislava (Slovakia), Chicago (United States), Southampton (England), Bournemouth (England), Brighton (England), Bristol (England), London (England), New Forest (England), Oxford (England), Portsmouth (England), Salisbury (England), Winchester(England), Amsterdam(Netherlands), Den Haag (Netherlands), Wageningen (the Netherlands), s-Hertogenbosch (Netherlands), Liége (Belgium),Florence (Italy), Nessebar (Bulgaria), Varna(Bulgaria) and various cities within our country (Istanbul, Hatay, Eskişehir, Bozcaada). In the light of all these data, the evaluation of the quality and use of hard landscape design elements was performed in line with the purposes of the research. At the end of the study new proposals as to the use of hard landscape design elements in landscape design works to be carried out within our country were brought in line with approaches in the world (Figure 1). 


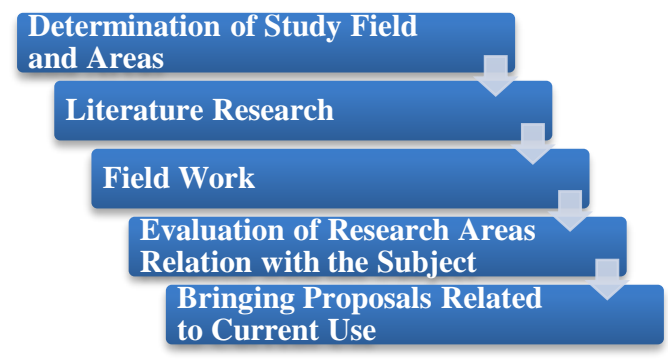

Figure 1. Stages of the study

\section{Results}

This part includes the findings and detectionsobtained subsequent to literature and field study and providing the data related to the subject within the scope of the study.

\section{Classical Usage Approach in Hard Landscape Design Elements}

Space denotes limited spaces. Space is loaded with emotions, expectations and aspirations and gain a meaning in the process of its being experienced (Sancak, 2009). The spaces exist as long as they can be perceived by people. Perception occurs by touching and smelling but primarily by senses of hearing and seeing. In other words, all of our sense organs provide us with information as to the places we live in.

We make the classification of architectural space and natural space according to the difference of the items which restrict the space. If these items include the walls, ceilings and floors, pillars, columns and beams then we classify this space as an architectural space. If these items include the earth, sky, horizon, bushes, trees and clouds then we classify this space as natural space made by nature. Urban spaces which are the special situation of architectural space or natural and architectural space are limited with streets, buildings or green areas, trees and etc. with them (Altan, 1992).

Landscape architecture targets discipline and creation of aesthetic and functional spaces which at the same time are compatible with humans and nature. Ensuring the comfort of the city and facilitation of human life in terms of functional, aesthetic and psychological aspects can be realized by designing of all kinds of materials, equipments and plants used in the city according to anthropometric measures. A person is in continuous interaction with the landscape elements around him in the city where he lives. He walks on sidewalks, sits on benches, uses bus stops and garbage cans and signs as well as utilizing directional plates and plants (Bilen, 2004).

User requirements in urban open spaces include experiences and activities which people think they like and it may vary from a comfortable entry which will allow them to enter the field easily to functions that will make them have a good time in an active or passive way. When an open space design is applied without considering these requirements well it is inevitable that there will be conflicts between the users and the space and the limited use of the space will lead to loss. The most important requirement in creation and maintenance of an open space in a successful way is to ensure people's utilization and enjoyment. Previous studies carried out on urban open space like parks and squares have revealed the fact that the prerequisite for a successful space is based on providing the basic requirements of people (İnan, 2008).

\section{Current Usage Approaches of Hard Landscape Design Elements}

When we examine the current use of hard landscape design elements, we see they are very different from the past. Fifty years ago hard landscape design elements consisted of limited materials such as walls, floors, pools and sculptures while in our day hard landscape design elements sometimes become a focal point or an artistic object or design thanks to the advantage of structural material diversity with economic, environmentalist, modern and other similar features. Most of the time, the materials we know are experienced in different roles.

This phase of the study is not related with a city and it has been planned to select more than one city and country in order to be able to examine influential and different hard landscape design elements, design disciplines, cultures, user behaviors and similar behaviors. Selected cities and countries have features such as being traditional, touristic and residential cities and countries in addition to their features as to nature. Current usage approaches of hard landscape design elements 
in United States, Europe and Turkey have been examined in a comprehensive manner as horizontal elements (floor elements) and vertical elements and some examples have been included in summary below in this study.

\section{Examination of Examples from Europe and the United States of America}

We can explain the current examples from Europe and the United States of America as regards research subject as follows:

Permeable flooring materials which allow rainwater to drain are used in parking lots in our day in which environmental awareness is gradually increasing (Figure 2).

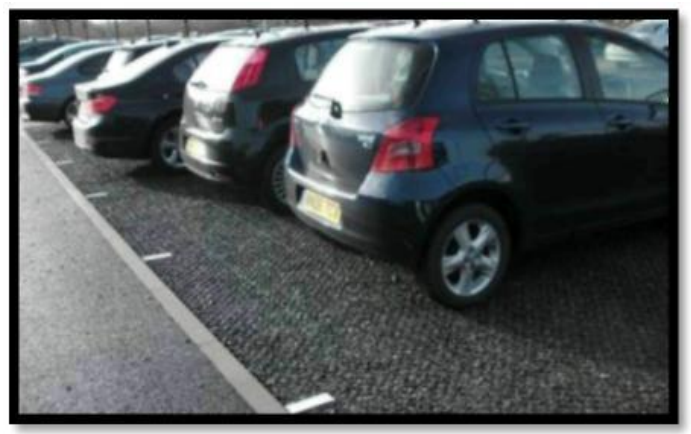

Figure 2: Permeable gravel filled parking lot of Bristol \& Bath Science Park in conformance with the principles of SuDS for 200 cars (Gravel-filled porous car parking, 2016)

Reduction of the heat island effect in the cities with high reflectance value (with high albedo) floor surfaces and minimized hard surfaces (Figure 3).

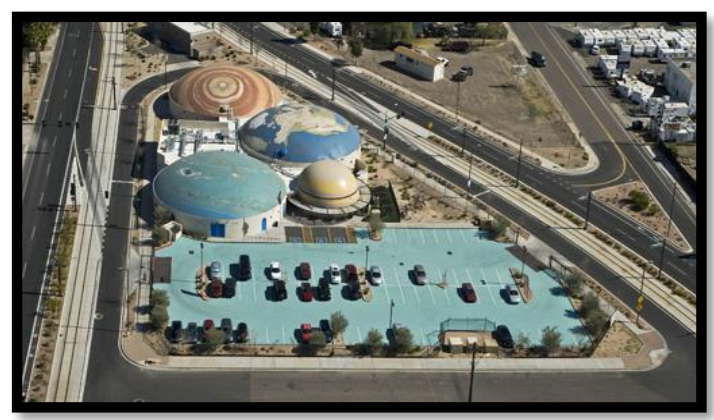

Figure 3: Emerald Cities тм "cool pavement coatings" reflecting the sun and "cold slurry seal" which are cold bituminous mortar coatings, first examples of which were observed in Phoenix Arizona, decrease asphalt surface temperature to $-6^{\circ}$ to $4^{\circ}$ and provide $\mathrm{CO}_{2}$ rate ate high temperatures (Emerald Cities Cool Pavement, 2016)

In squares where the soil does not allow plant growth or where there is not enough soil, there are solutions by usage of the flooring elements like giant pots which can take plant roots inside on the pavements and which are aesthetic at the same time (Figure 4, Figure 5)

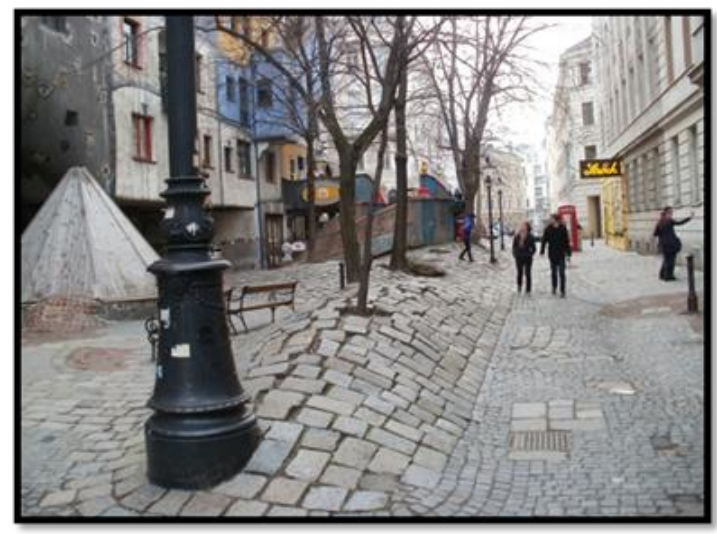

Figure 4: Pedestrianized street of Hundertwasser House, Vienna which attracts many tourists (Photo: Altınçekiç, 2015)

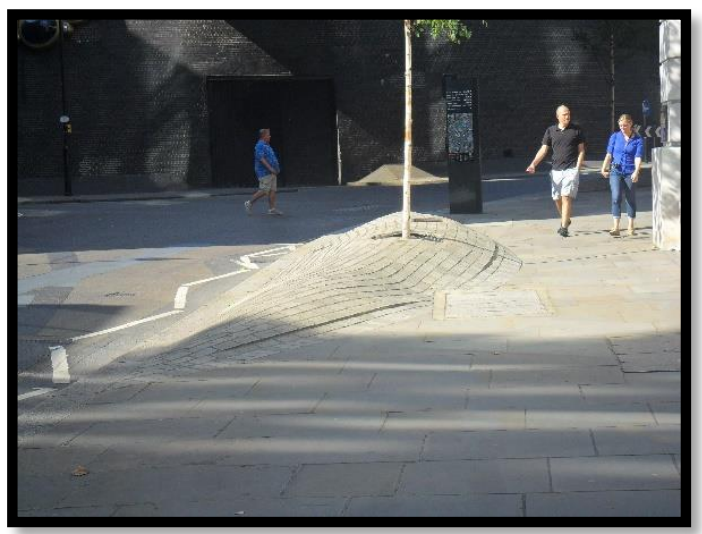

Figure 5: A similar example of application on a sidewalk in London Wall region where pedestrian traffic and the number of tourists is quite intensive, London (Photo: Şentürk, 2014)

Mulch applications which have began to be frequently seen in squares, terraces and even walking trails (Figure 6). 


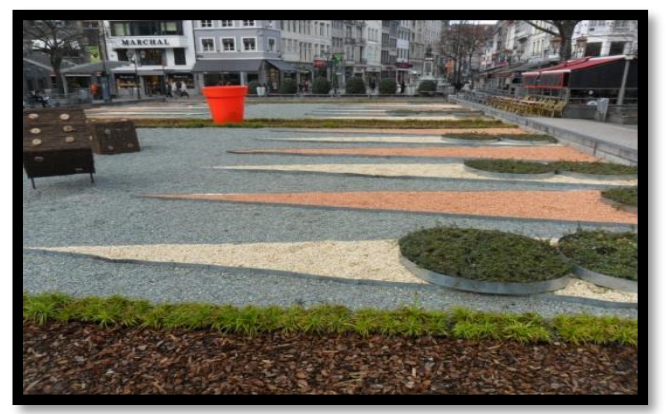

Figure 6: Example of Place de la Cathédrale, Liege (Photo: Şentürk, 2015)

Bicycle ramp applications are used to move bicycles up or down the stairs located near subways, train stations or open spaces in cities where bicycles are used extensively (Figure 7).

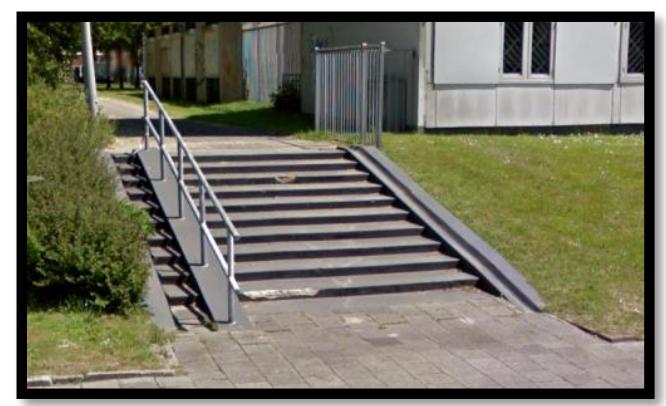

Figure 7: An example of a bike ramp in Westlangracht, Amsterdam (Photo: Şentürk, 2015)

It is given importance to give aesthetic function to stairs to bring activity to the place besides their functional characteristics in urban outdoor spaces (Figure 8).

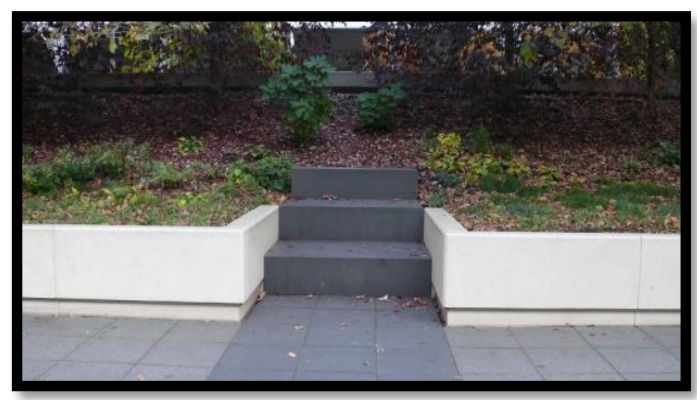

Figure 8: An example of stairs used for sitting outside its main function, Chicago (Photo: Altınçekiç, 2010)

There are applications in various cities of
Europe and America as regards the usage of hard floors with concrete or different ground which serve as ornamental pool or for different recreational purposes in the summer and for ice skating in the winter (Figure 9).
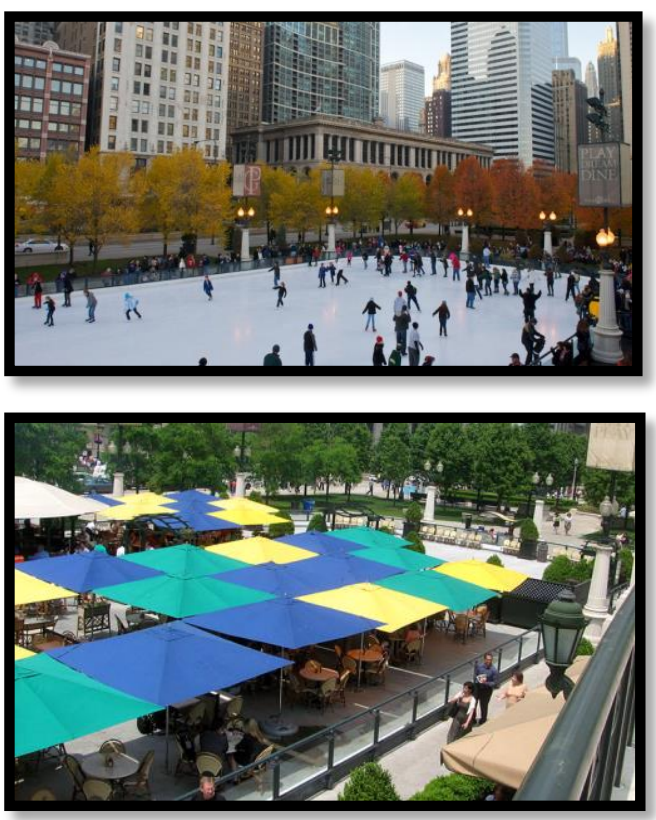

Figure 9: McCormick Tribune Plaza in Chicago. The picture above was taken in winter where it is used as the ice-skating rink (Ice Skating in Chicago's Millenium Park, 2011) while the picture below was taken in summer (McCormick Tribune Plaza \& Ice Rink, 2008)

The sitting units which are designed, in addition to considering their function, by taking into account their aesthetic properties like the natural or artificial materials used and their color and shape (Figure 10).

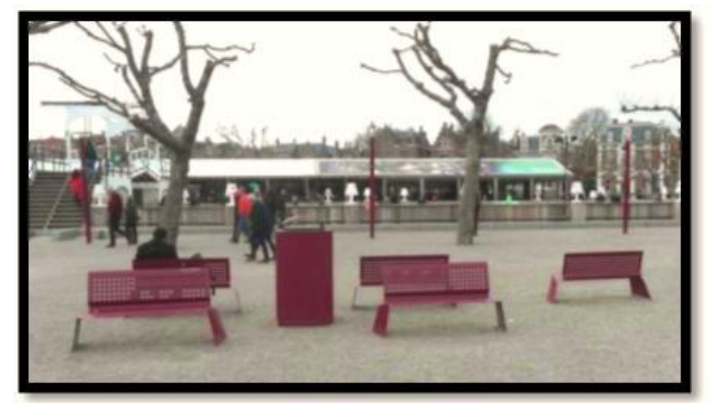

Figure 10: Sitting units compatible with lighting and garbage containers made of pink color and metal material contrasting with green and gray, Amsterdam (Şentürk, 2015) 
Designs of sitting units are made with original, aesthetic and versatile usability features making positive contributions to urban aesthetics and identity in addition to their sitting function (Figure 11).

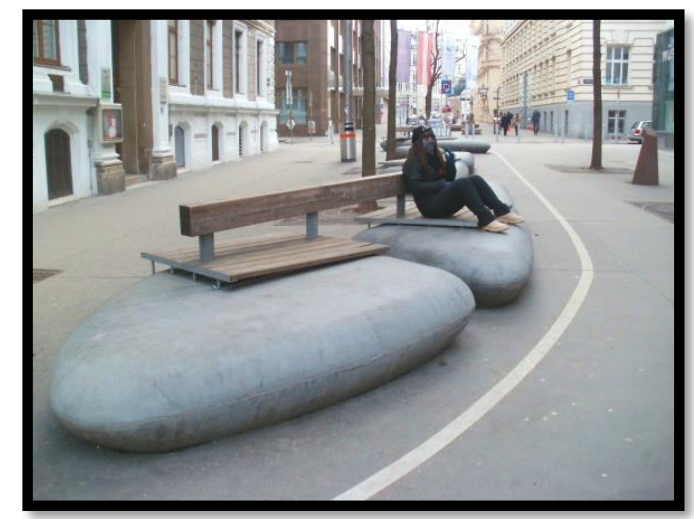

Figure 11: Versatile sitting units on which tired people can comfortably rest, Vienna (Photo: Altınçekiç, 2015)

Integration of technological developments with urban furniture (Figure 12).

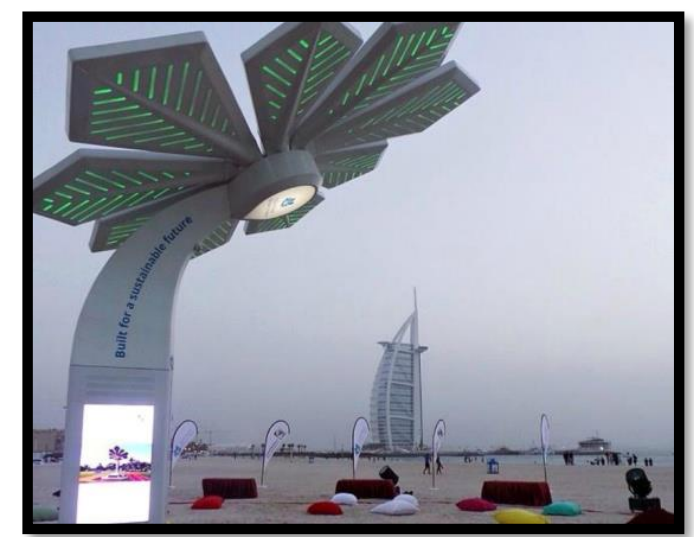

Figure 12: Solar powered palm tree (Robarts, 2015) in Dubai which provides wi-fi, by which phones and tablets can be charged, weather and sea conditions can be learned and which can be used as night lighting (Robarts, 2015).

Bollards, which are compatible with material and design of the texture of the area where they are used, have been used for protecting people, trees, structures from moving vehicles in areas where there is intensive vehicle traffic or traffic is dangerous and for separating spaces from each other (Figures 13, 14).

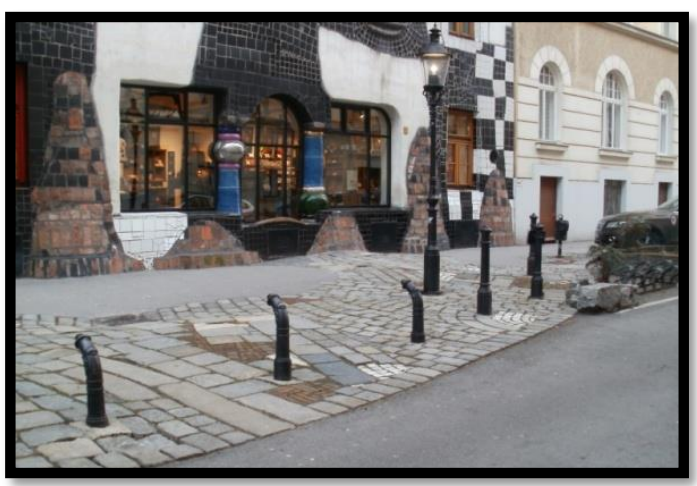

Figure 13: Examples of bollards compatible with architecture of the Hundertwasser house, Vienna (Photo: Altınçekiç, 2015)

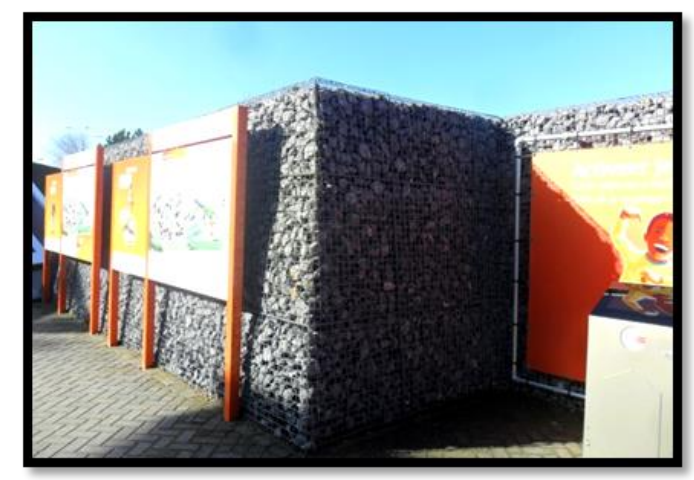

Figure 14: Examples of gabion walls which we recently see often in our day, Den Haag (Photo: Şentürk, 2015)

As in all hard landscape design elements, feature of being aesthetic and functional is also an important issue in water elements. Aesthetic practices which do not have bad appearance when water does not flow or when there is no water are applied (Figure 15).

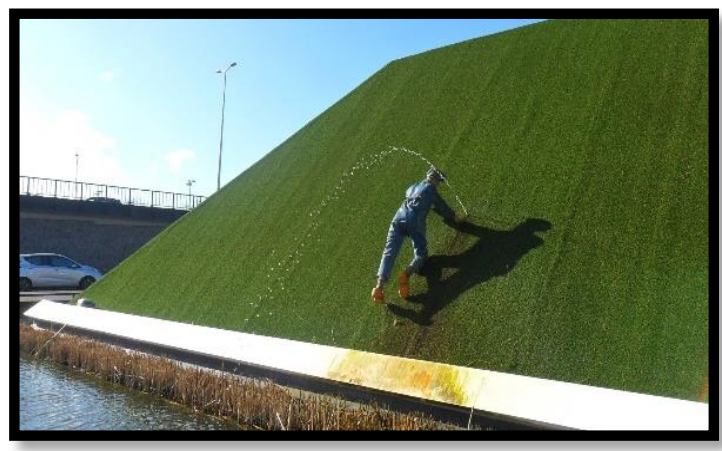

Figure 15: Examples of water elements made with humoristic approach. Den Haag (Photo: Şentürk, 2015) 
We observe sales units in the form of booths, newspaper sales elements, sales and rental kiosks, ATMs and modular cabin units at places where pedestrian circulation is intense (Figure 16).

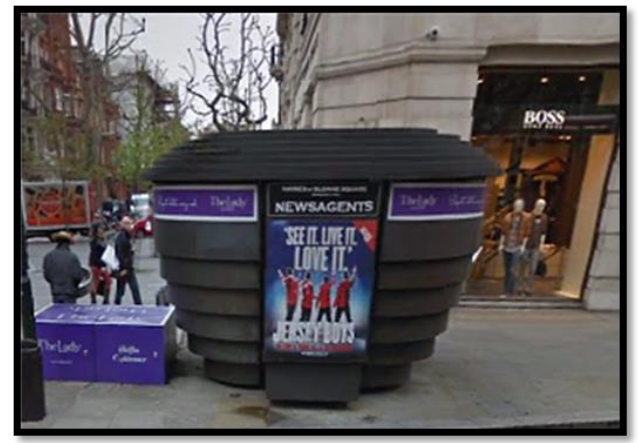

Figure 16: Paper House in Royal Borough, Sloane Square, and Earl's Court made by Heatherwick Studio, London (Photo: Senturk, 2015)

Application of artistic objects, which increases the visual value of landscape, renders design more effective and perceptible, meets psychological and sociological requirements of users and are used as hard landscape design elements have begun (Figure 17,18).
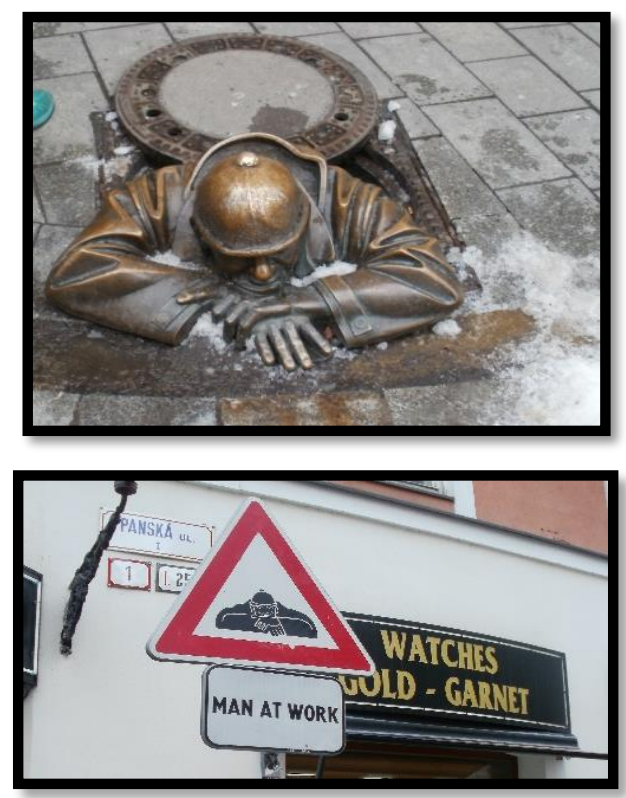

Figure 17: The Watcher 'Man at Work' sculpture which has become one of the symbols of Bratislava (Photo: Altınçekiç, 2015)

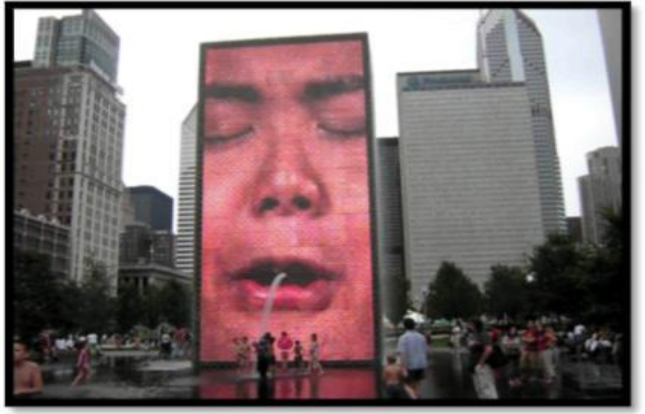

Figure 18: Chicago's world-famous digital public art collection where social inclusion is not disregarded (Untitled, Millennium park led screen, 2016)

Applications of contemporary children's playgrounds are made increasingly instead of conventional playing elements (Figure 19).

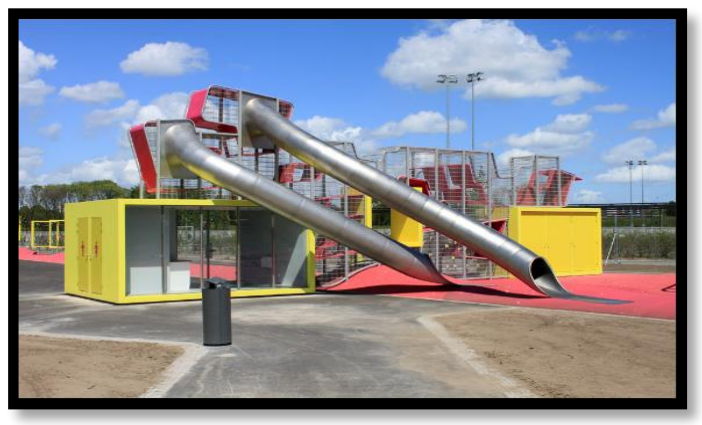

Figure 19: Examples from Bijlmerpark with an area of $8400 \mathrm{~m}^{2}$, Amsterdam (Hi-design International Publishing, 2014)

Applications of bicycle parking elements designed to ensure bicycle users to easily park their bicycles are often seen in line with the increase in bicycle rental places (Figure 20).

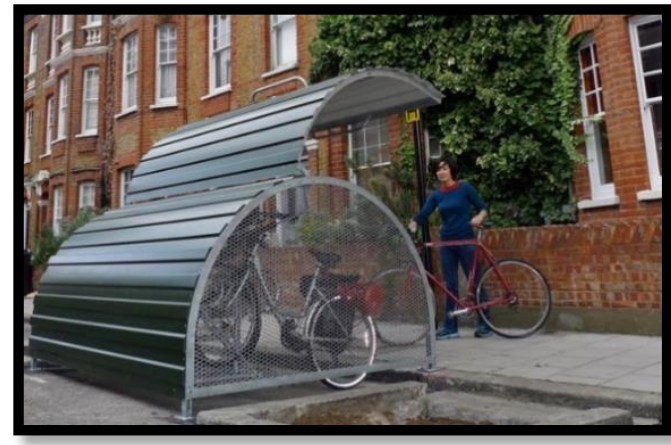

Figure 20: Bicycle parking elements which have began to be used in residential areas in London (London Cycling Campaign, 2013) 
City gates which are in the form of plates, signs, sculptures or door frames in appearance and architecture have begun to give identity to urban spaces due to their location both at entrance or exit of streets and at entrance or exit of cities (Fig. 21).

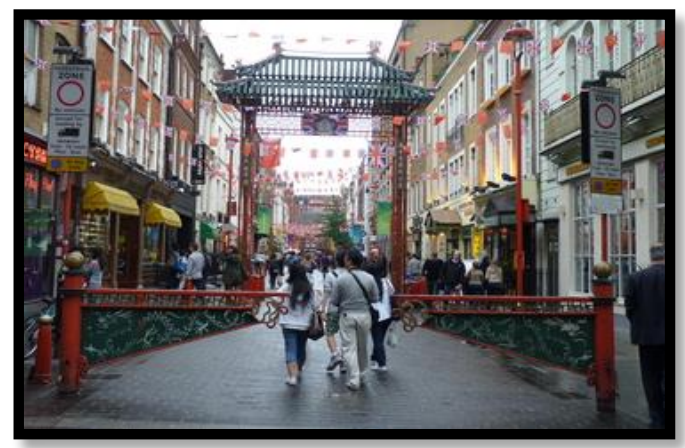

Figure 21: The door frame at the entrance of Chinatown in Soho district one the one hand indicates the location and on the other hand surrounds the street (Bathe, 2012)

Pantomime artists performance as living statues on the urban squares or designs and practices that attract the attention of tourists can be given as current examples (Figure 22).

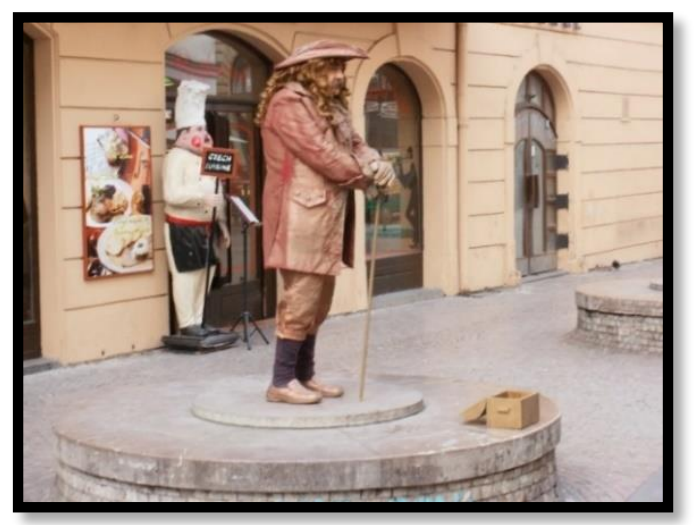

Figure 22: An example of a street artist in the streets of Prague (Photo: Altınçekiç, 2015)

\section{Examination of examples from Turkey}

We can show the current examples of hard landscape design elements used in parks, green spaces, squares and similar areas made in Turkey related to the subject of the study at this stage as follows:
Applications made with sustainable landscape elements instead of asphalt are recently observed in the parking lots (Figure 23).

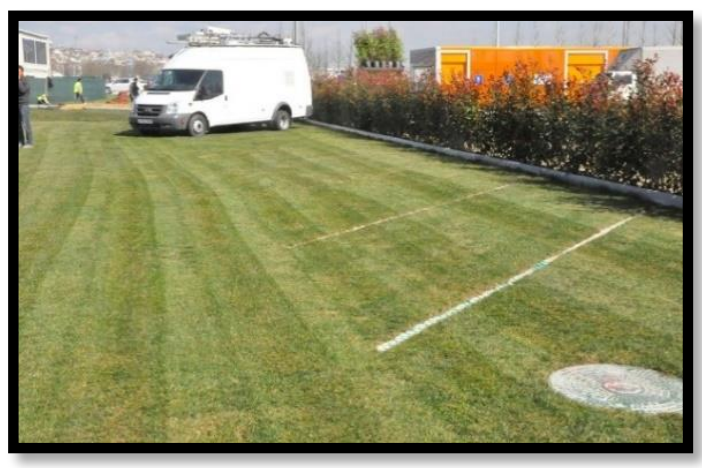

Figure 23: Live green grass Ecogrid paving of parking lot with protection for grass used in Yenikap1 City Park rally site (Ecological ground, 2016)

The idea of creating an artificial beach with real sea sand in order to meet the beach requirement of people who cannot go to holiday which has started in important city centers like Milan and Paris in Europe has been in service in Kentpark of Eskişehir province in Turkey since 2008 (Figure 24).

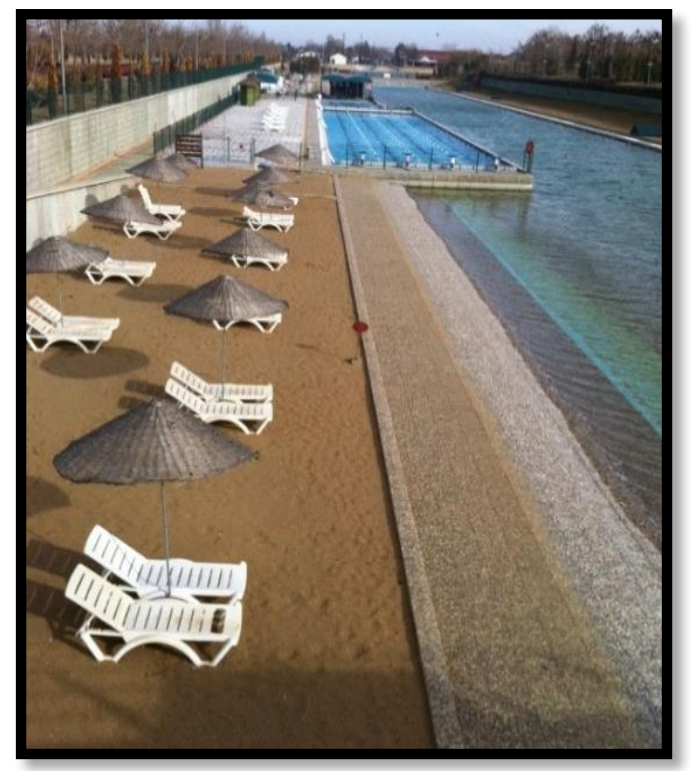

Figure 24: A view from Turkey's first artificial beach created by using real sea sand, Eskişehir (Photo: Altınçekiç, 2015).

Unique, aesthetic and versatile designs providing positive contributions to urban 
aesthetics and urban identity, in addition to their sitting function, have started to be applied (Figure 25).
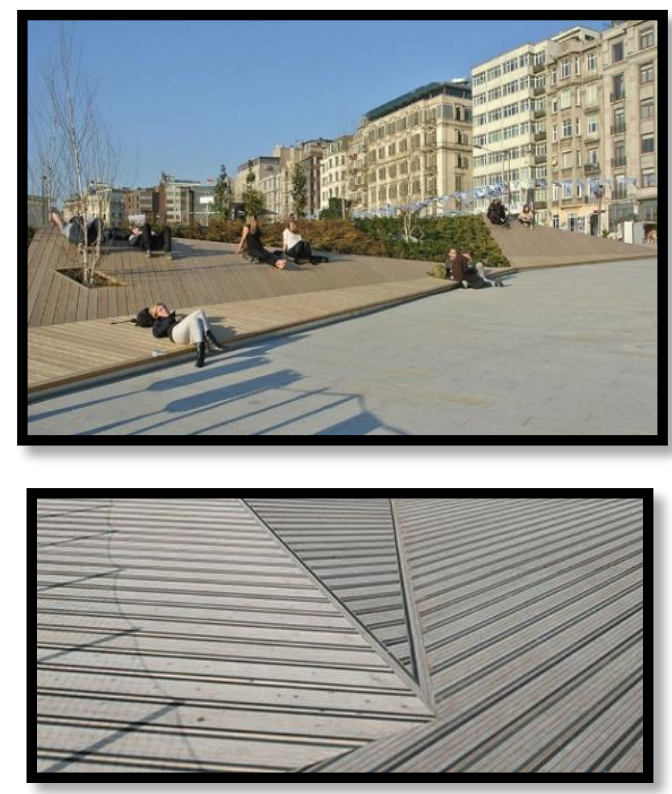

Figure 25: Sitting units designed in Sishane Park (Sishane Park, 2014)

Sheltering items providing shadow, rain protection, rest and passive recreation possibilities give aesthetic properties to the areas where they are located (Figure 26).

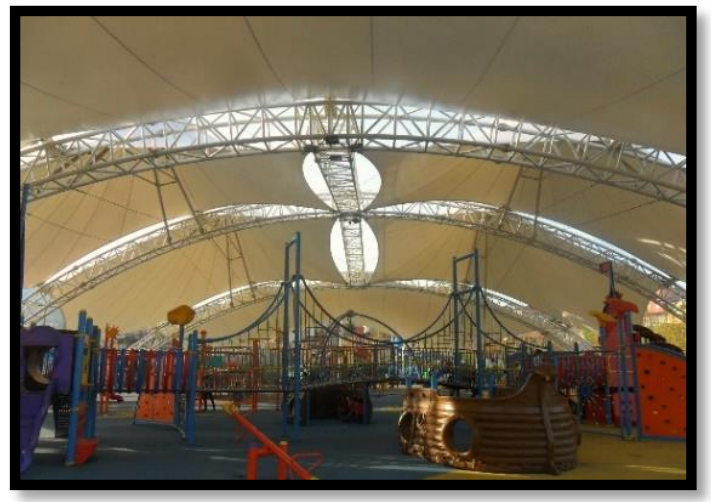

Figure 26: Examples of sheltering items for children's playground, Sultanbeyli Pond Park (Photo: Şentürk, 2015)

Artistic object applications, used as hard landscape design elements, making design more effective and perceptible and meeting psychological and sociological requirements of users increase the visual value of the landscape (Figs. 27, 28).

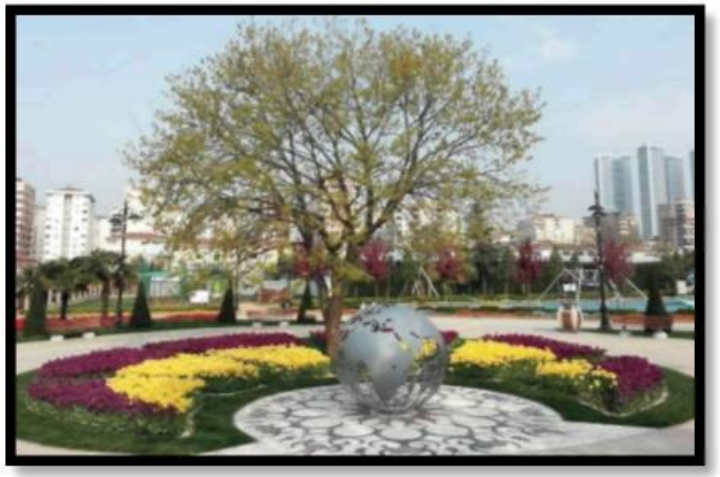

Figure 27: Examples of art objects in the $60^{\text {th }}$ Year Park of Göztepe district (Göztepe $60^{\text {th }}$ Year Park, 2016)

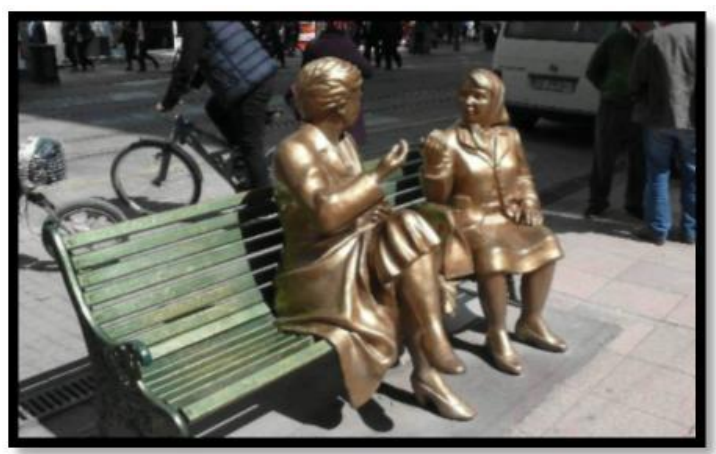

Figure 28: An example in a street of Eskişehir province (Photo: Altınçekiç, 2016)

Applications of contemporary children's playgrounds instead of conventional playing elements increase each and every day (Figure 29).

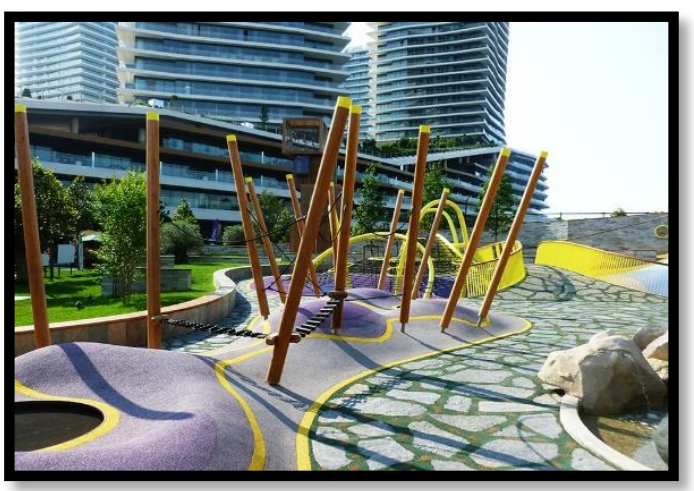

Figure 29: Examples from the children's playground at Zorlu Center (Zorlu Playground Carve Landscape Architecture, 2014) 
Flowerpot applications, made by recycled materials providing positive contributions to street art. (Figure 30).
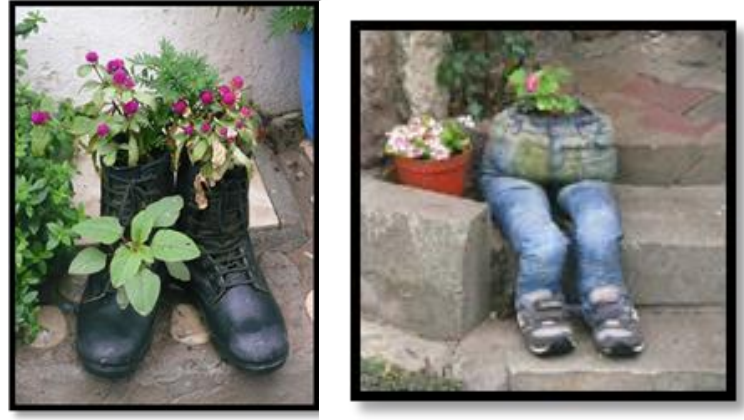

Figure 30: Examples from the Streets of Bozcaada district (Photo: Altınçekiç, 2015)

City gates which are becoming increasingly common have begun to give identity to urban spaces due to their location both at entrance or exit of streets and at entrance or exit of cities (Fig. 31).

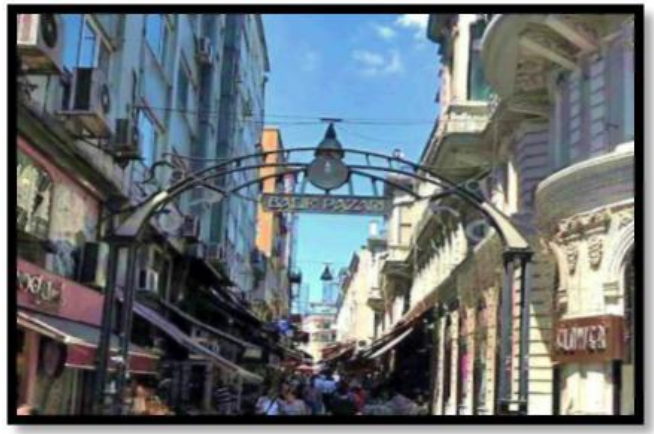

Figure 31: An example of city gate in Balık pazar1 (Fish market) district of Istanbul (Photo: Şentürk, 2015).

Designs which attract the attention of people and tourists are made in areas such as urban squares, streets and parks (Figure 32).

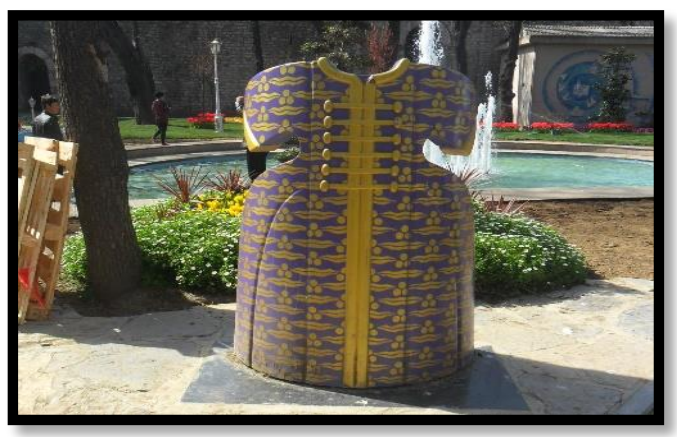

Figure 32: A caftan (a man's long belted tunic, worn in countries of the Near East.) in
Gülhane Park for taking photos by placing your head and arms on it, Istanbul (Photo: Şentürk, 2016)

The street art called moss graffiti or green graffiti combining plants in the urban environment without damaging with hard landscape design elements and making them more visible can be given as current examples as to the subject of research from our country (Figure 33).

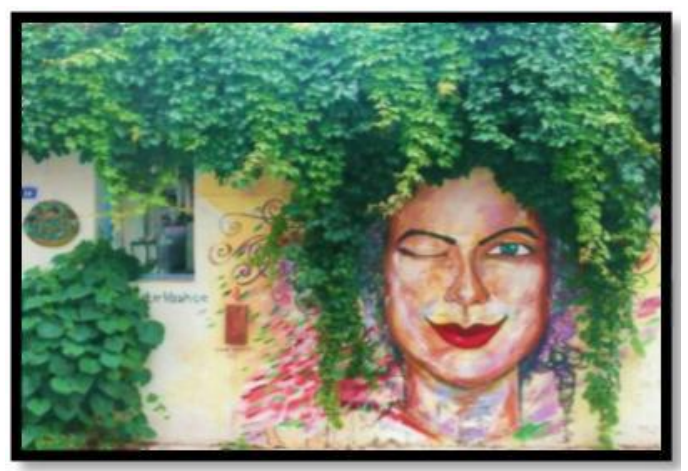

Figure 33: An example of wall with moss graffiti in Bozcaada island (Photo: Altınçekiç, 2015)

\section{Discussion and Conclusion}

Hard landscape design elements both establish the connection between nature and people and the connection between streets and people. Approaches as to information, designs and experiences transferred from the past as to landscaping has changed due to rising of living standards in the recent years and this case has also changed the expectations from hard landscape design elements. On the other hand factors such as decrease in green spaces in line with the high amounts of concrete usage in cities and climate changes have caused the emergence of ecological and sustainable design approaches as regards hard landscape design elements to contribute to the ecosystem of the city. It is seen that some hard landscape design elements designed and used in our country pace with new developments and we can list new proposals which can contribute to the use of hard landscape design elements in addition to these developments as follows:

Hard landscape design elements should be designed by considering energy efficient landscaping and arid landscape approach. It is 
necessary to increase the utilization of permeable surfaces for saving water as an alternative to standard flooring materials, in pedestrianized ways and areas which will not affect groundwater in a negative way. Water accumulation on the surfaces will be prevented by the utilization of permeable surfaces and feeding of groundwater will be ensured through leakage or storage. Low border applications, which are also made within the context of rain water management, create a remarkable design opportunity in the field which is applied by their similarity to pots due the usage of grids in addition to the ecological benefits provided thereby.

Use of high-albedo material should be given importance in order to prevent or reduce the effect of formation of urban heat island effect. Furthermore, it has been revealed that use of light colored materials leads to savings in night lighting.

It is necessary to ensure the re-use of materials and stuff in the area in an arrangement made for the area.

It should be started to make applications such as the use of modular hard landscape design elements such as recycled aggregate, concrete, lock paving stone or narrowing of traffic routes in order to reduce material consumption.

Priority should be given to the construction of separate lanes for public transport vehicles and bicycle lanes with a view to reduce energy consumption. Furthermore, it is also important to give importance to the consumption of electricity which has very high cost. Lamps with less consumption and solar-powered lighting elements should be preferred.

Policies as to the use of recycled garbage bins, raising awareness in people and participation of the people should be followed in order to create a healthy environment with hard landscaping elements.

More attractive maintenance covers with a specific standardization and size symbolizing the city in which they are placed or its history should be used in historical, touristic and official areas in Turkey like abroad.

"Design flexibility" should be prioritized in design of hard landscape design elements and designs which can adapt to conditions that may change in the future should be made.
General conclusions as to new approaches in hard landscape design elements and their use can be listed as follows:

It is observed that the arid landscape understanding, which is one of the new approaches, is adapted to hard landscape design elements due to excessive increase of hard surfaces in urban areas. We see that permeable flooring is preferred, rain gardens are made and drainage systems are combined with curbs and grass plate stones in many cities of the world. Similar implementations should be realized urgently in our country.

Differences were created in guide roads with different colors and textures in entering and existing settlements from vehicle roads, at the intersections without traffic signs, on pedestrian passing zones, in traffic speed cutter applications, in the pedestrianized roads and parking lots for visually impaired people. In addition to the use of embossed stones as a guide road for individuals with disabilities, it should be given importance to use of them as a danger warning in dangerous places for all users.

Efforts should be made to apply and increase flexibility in design, sustainable and ecological designs, universal and unobstructed designs, and designs created by public participation as well as human-focused designs.

The use of hard landscape design elements which are in harmony with each other and with the historic buildings and structures that exist in historical places and which reflect the history, culture and traditions as well as the history of the area should be emphasized.

Applications such as the use of low-energy lighting (LED) or solar photovoltaic systems to reduce energy consumption, as well as combining traffic signs, lighting, flowerpots, billboards and etc. on the same pole must be realized since this will require fewer infrastructures and prevent bad appearance.

As a result, the following factors have a significant effect on design of hard landscape design elements of our day: geography and climatic conditions, history, culture, traditions, people's lifestyle and behaviors, developing technology and changing cultures in line with it and the ecological situation of the world. 
Approaches in the use of hard landscape design elements seen in cities of developed countries must be applied in a widespread way in our entire country like they are especially applied in İstanbul and Eskişehir. Only in this way, hard landscape design elements can be functional, aesthetic and ecological and provide the comfort of the users, contribute to the urban identity and respect the nature.

\section{References}

Akdoğan, G. (1974). Bahçe ve peyzaj sanatı tarihi. Ankara: Ankara Üniversitesi Yayınları.

Alexander, R. (2009). The essential garden design workbook. Oregon: Timber Press Inc. ISBN13: 9780881929751.

Altan, İ. (1992). The concept of space in architecture. Yildiz Technical University applied technology center for settlement and architectural sciences.

Başer, B. (2002). The Evaluation of Bursa Soğanl Botanical Park's hard landscape design in the functional and aesthetical aspects, Master, ITU Graduate School of Science Engineering and Technology.

Bathe, J. (2012). A walk in Chinatown, London, http://www.weekendnotes.co.uk/chinatownlondon/

Bilen, S. Ö. (2004). The investigation of landscape staff given in Ankara example depending on anthropometric data in designing urban outdoor areas, Doctorate, Ankara University, Graduate School of Natural and Applied Sciences.

Bird, C. (2014). The fundamentals of horticulture. Spain: Cambridge University Press ISBN-13: 978-0521707398

Blake, J. (2015). An introduction to landscape and garden design. Routledge, Surrey, England. ISBN-13: 978-0754674863.

Ecological ground. http://www.ekoplas.com/Referanslar

Emerald Cities Cool Pavement. (2016). http://www.emeraldcoolpavements.com/

Genç, G. (2006). The effects of landscape design elements on energy saving, Master, ITU Graduate School of Science Engineering and Technology.

Göztepe 60 th Year Park. (2016). http://www.anadoluparkbahceler.com/index.ph $\mathrm{p}$

Gravel-filled Porous Car Parking. (2016). http://www.terram.com/projects/gravel-filledporous-car-parking-bristol-science-park-sparkone.html
Hi-design International Publishing. (2014). World of the child heart. (Chinese Edition), China: Guangxi Normal University Press.

Ice Skating in Chicago's Millenium Park. (2011). https://rickholliday.wordpress.com/2011/12/27/ ice-skating-in-chicagos-millenium-park/

İnan, Z. (2008). Design of urban open spaces for user needs. Artvin Çoruh University, Faculty of Forestry Journal, 9 (1-2), 12-23.

Landscaping Supplementary Planning Document (Landscaping $\quad$ SPD). https://www3.havering.gov.uk/Documents/Pla nning/LDF/Landscaping-SPD.pdf

London Cycling Campaign. (2013). http://lcc.org.uk/articles/cyclehoop-bringsdutch-style-secure-residential- cycleparking-tosix-london-borough

McCormick Tribune Plaza \& Ice Rink. (2008). https://en.wikipedi.org/wiki/McCormick_Tribu ne_Plaza_\&_Ice_Rink\#/media/File:20080602_ Park_Grill_Plaza_from_AT\%26T_Plaza.JPG http://karlatour .kz/ photo_r e port $/ 238$

Punter, J. \& Carmona, M. (2011). The design dimension of planning: Theory, content and best practice for design policies. London: E \& FN Spon. ISBN-13: 978-0415512282.

Robarts, S. (2015). https://newatlas.com/smartpalm-wi-fi-charging-palm-tree-dubai/37984/

Sagers, L. A. (2005). Designing Hardscapes, http://digitalcommons.usu.edu/cgi/viewcontent .cgi?article=2343\&context=extension_his tall

Sancak, A. (2009). An analysis of the city furniture planning in the urban location identity formation. Master, Mimar Sinan Fine Arts University, Graduate School of Natural and Applied Sciences.

Shakouri, N. (2010). An assessment of construction materials used in landscape design and implementation from the perspective of historical period. Master, Ankara University, Graduate School of Natural and Applied Sciences.

Sishane Park. (2014). httpwww.landezine.com/in dex.php/2014/11/sishane-park-by-sanalarc/

Untitled, Millennium park led screen, (2016). http://s56.photobucket.com/user/deeelovely/me dia/DSCN4322.jpg.html

Yildizc1, A. C. (2001). The Concept of Urban Street Furniture and Analysis of Street Furnitures in İstanbul, I. International symposium for street furniture, Istanbul Metropolitan Municipality, İstanbul, 29-34.

Zorlu Playground Carve Landscape Architecture. (2014).

http://www.Landezine.com/index.php/2014/08/ playground-at-zorlu-centre-by-carve/ 